\title{
Study on the Adipose Tissue Cellularity and the Lipid Metabolism in Two Lines of Mice Selected for High and Low Resistance to Starvation
}

\author{
Keiichi Suzukr, Toshihiro Yamagishi and Yutaka Mizuma \\ Department of Animal Science, Faculty of Agriculture, \\ Tohoku University, Sendai-shi, 980
}

(Received August 22, 1979)

\begin{abstract}
In order to clarify the difference in the lipid metabolism between two lines of mice selected for high and low resistance to starvation (SH and SL), the changes of chemical body composition, total lipid, total cholesterol and glucose in plasma, cellularity and lipase activity of epididymal adipose tissue and lipid synthesis in the liver under starvation were investigated. Both under normal control (45 days of age) and starvation ( 48 hours from 45 days of age) conditions, there was no difference in body weight between SH and SL lines, while SH line had more body fat and less water, and statistically not significant but less fat free dry matter content than SL. In the normal control, SH line was higher than SL in plasma total cholesterol and glucose. It was clarified that SH was larger than SI in adipose fat cell size, but there was no significant difference in fat cell number between two lines. The total lipase activity of the epididymal adipose tissue of SH line was significantly higher than that of SL in the normal control. And under starvation condition, although the difference was not statistically significant, the activity of SH line was also higher than that of SL. There was no significant difference in liver lipid content between two lines but the incorporation of $1^{-14} \mathrm{C}$-acetic acid into liver lipid of SH line surpassed that of SL. From these results, it was concluded that the difference in body fat content between SH and SL lines selected for resistance to starvation was accounted for by the adipose tissue cell size which was brought about as the correlated genetic response in the lipid metabolism between SH and SL lines.
\end{abstract}

Jpn. J. Zootech. Sci., 51 (4):293-300, 1980

If there is the genetic variation in the ability of adaptation to qauntitative nutritional deficiency, it is very important to take the selection for this character into livestock improvement. For this purpose, the selection of mice for the resistance to starvation was conducted by Yamagish ${ }^{11}$. The mice selected for high resistance (SH) had more fat, and less water and protein than those selected for low resistance (SL) ${ }^{2)}$. Furthermore, when the body weight of two lines of mice were restricted by food, SL line lost body fat, but SH line didn' ${ }^{2}$. And SH line had more liver DNA content and less RNA/DNA than $\mathrm{SL}^{3}$. These results may suggest that there is a difference in lipid metabolism between SH and SL lines.

In the present study, in order to clarify the difference in the lipid metabolism between SH and SL lines, the changes of chemical body composition, total lipid, total cholesterol and glucose in plasma, epididymal fat cell size and number, adipose tissue lipase activity and ${ }^{14} \mathrm{C}$ incorporation into liver lipid under starvation were investigated. 


\section{Materials and Methods}

Animals: Experimental animals were derived from two lines of mice selected for high $(\mathrm{SH})$ and low (SL) resistance to starvation. The selection procedure of these lines was described by Yamagishi ${ }^{11}$. Male mice of each line were sacrificed by decapitation at 45 days of age in normal control group and after 48 hours of starvation from 45 days of age in starvation group in following three experiments.

Experiment 1: After removing the gastrointestinal tract, liver and epididymal adipose tissue, carcasses were frozen until analysis. The carcasses were weighed and dried until constant weight was attained in vaccum dry oven at $70^{\circ} \mathrm{C}$ for 48 hours. The carcass fat was determined by ether extraction. Total lipid, total cholesterol and glucose in plasma were determined by the method of Sulfo-phospho-vanillin reaction"), ZURKowsKI $^{5)}$ and Glucose Test Wako, respectively.

Liver lipid content was determined by weighing the lipid extracted by the method of BLIGH and DYER ${ }^{6}$. About $0.1 \mathrm{~g}$ of wet liver tissue was dried in an oven for 24 hours at $90^{\circ} \mathrm{C}$ and liver moisture was determined.

The epididymal adipose tissue was divided into two portions: one for adipose cell size determination (about $100 \mathrm{mg}$ ) and the other for the determination of lipid content (about $100 \mathrm{mg}$ ) extracted by the method of BLIGH and DYER ${ }^{6}$. Fat cells were isolated from epididymal adipose tissue of the mice by the method of RonBELL ${ }^{7}$. The diameter of the 200 fat cells from the same population was measured with a microscope using an eyepiece micrometer at a magnification of $\times 70$. The sizing of 200 fat cells was performed within 15 minutes. Fat cell volume $\left(\pi \mathrm{D}^{3} / 6\right)$ was calculated by the data on diameters (D) of 200 fat cells in suspension. The number of fat cells of adipose tissue could be obtained by dividing the total lipid content of the tissue by the average lipid content of a fat cell. The average lipid content of a fat cell was derived from the mean cell volume $\times$ density $(0.915)$ of lipid.

Experiment 2: The epididymal adipose tissues of normal control and starvation groups from each line were quickly removed and weighed. Epididymal adipose tissue was homogenized in a $0.06 \mathrm{M}$ phosphate buffer ( $\mathrm{pH} 7.4$ ). Lipase activity was measured by adding $0.5 \mathrm{ml}$ of this homogenate to $0.45 \mathrm{ml}$ of $0.06 \mathrm{M}$ phosphate buffer containg $5 \%$ albumin and $0.05 \mathrm{ml}$ of Ediol (a commercial emulsion of $50 \%$ coconut oil) solution diluted with 4 volumes of water. Incubation was performed at $37^{\circ} \mathrm{C}$ for 60 minutes. After incubation, free fatty acids were measured by the method of NEFA Test Wako. The enzyme acitivity was defined as $\mu \mathrm{Eq}$ of free fatty acid released per $g$ of wet adipose tissue and expressed as the total activity in the whole tissue.

Experiment 3: One $\mu \mathrm{Ci}$ radioactive acetate was injected intraperitoneally per $20 \mathrm{~g}$ of body weight of normal control group animals. The dose was doubled in the starvation group animals. In the present experiment, the animals were killed at 30 minutes after the injection, as VAN BRUGGEN et al. ${ }^{8)}$ have shown that in mice maximum incorporation of an injected tracer amount of acetate- $1{ }^{-14} \mathrm{C}$ occured within 30 minutes after 
the injection with no further change up to 8 hours. The lipid extraction from liver was done by the method of BLIGH and DYER ${ }^{6}$. After evapolating the chloroform in the vials, ten $\mathrm{ml}$ of scintilation fluid (5 $\mathrm{g}$ PPO and dimethyl-POPOP per liter of toluene) was added and radioactivity in total lipid was measured by a fluid scintilation counter.

For statistical analysis, analysis of variance was adopted to detect line differences.

\section{Results}

The chemical body composition, total lipid, total cholesterol and glucose in plasma of SH and SL lines of mice of normal control and starvation groups are given in Table 1. There were no differences in body weight and FFDM (Fat Free Dry Matter) between SH and SL lines and between the treatment groups. But SH line had significantly more fat and less water than SL. In the starvation group, body weight and body fat percentage were reduced and FFDM percentage was increased as compared with the normal control group in both lines. In the normal control group, SH line had more total lipid, total cholesterol and glucose in plasma than SL. Plasma total lipid was unchanged but plasma total cholesterol increased whereas plasma glucose decreased under starvation in two lines.

The epididymal fat pad weight, fat cell diameter, fat cell volume and number of both lines and groups are given in Table 2. The SH line had significantly heavier epididymal fat pad weight and larger fat cell diameter and cell volume than SL. And there was no difference in fat cell number between two lines. In the starvation group, fat pad weight, fat cell diameter and cell volume but not fat cell number were smaller than in the normal group. The phenotypic correlations among body weight, epididymal fat pad weight and adipose cellularity traits pooled within group-line subclasses

Table 1. Chemical body composition, plasma lipid and glucose concentration of SH and SL lines.

\begin{tabular}{|c|c|c|c|c|c|c|c|c|c|}
\hline \multirow[b]{2}{*}{ Treatment } & \multirow[b]{2}{*}{ Line } & \multirow{2}{*}{$\begin{array}{c}\text { Number } \\
\text { of } \\
\text { mice }\end{array}$} & \multirow{2}{*}{$\begin{array}{c}\text { Body } \\
\text { weight }\end{array}$} & \multicolumn{3}{|c|}{ Chemical body composition } & \multicolumn{3}{|c|}{ Plasma } \\
\hline & & & & Water & Fat & FFDM $^{11}$ & $\begin{array}{l}\text { Total } \\
\text { lipid }\end{array}$ & $\begin{array}{c}\text { Total } \\
\text { cholesterol }\end{array}$ & Glucose \\
\hline \multirow{5}{*}{ Normal } & & & (g) & $(\%)$ & $(\%)$ & $(\%)$ & $(\mathrm{mg} / \mathrm{d} l)$ & $(\mathrm{mg} / \mathrm{d} l)$ & $(\mathrm{mg} / \mathrm{d} l)$ \\
\hline & $\mathrm{SH}$ & 6 & $28.03^{2)}$ & 61.88 & $15.12^{* * 31}$ & 23.01 & 618.40 & $218.40 * * *$ & $213.67^{* * *}$ \\
\hline & & & 0.79 & 1.53 & 2.23 & 0.54 & 86.93 & 14.33 & 14.02 \\
\hline & SL & 6 & 27.44 & $66.35^{* * *}$ & 9.84 & 23.81 & 608.69 & 174.03 & 185.89 \\
\hline & & & 0.68 & 1.71 & 3.20 & 1.56 & 47.76 & 12.99 & 10.89 \\
\hline \multirow{4}{*}{ Starvation } & $\mathrm{SH}$ & 6 & 22.29 & 61.84 & $12.33 * * *$ & 25.83 & 608.69 & $248.49(5)$ & $71.17(4)^{4}$ \\
\hline & & & 0.71 & 1.43 & 1.53 & 0.87 & 105.28 & 33.16 & 13.15 \\
\hline & S L & 6 & 22.25 & $66.52 * * *$ & 5.63 & 27.86 & $574.26(4)$ & $216.44(4)$ & $79.33(2)$ \\
\hline & & & $\therefore 16$ & 1.33 & 2.46 & 1.83 & 141.78 & 10.96 & 16.97 \\
\hline
\end{tabular}

1): FFDM: Fat Free Dry Matter, 2): Mean \pm S.D. 3): Significant difference between SH and SL lines. $\left.{ }^{* *} \mathrm{P}<0.01 .{ }^{* * *} \mathrm{P}<0.001 .4\right)$ : Number of mice. 5): The mice of normal control group were killed at 45 days of age and of starvation group were after 48 hours starvation from 45 days of age. 
Table 2. Epididymal adipose tissue weight, cell diameter, cell volume and cell number of $\mathrm{SH}$ and SL lines.

\begin{tabular}{|c|c|c|c|c|c|c|c|}
\hline \multirow[b]{2}{*}{ Treatment } & \multirow[b]{2}{*}{ Line } & \multirow{2}{*}{$\begin{array}{l}\text { Number } \\
\text { of mice }\end{array}$} & \multirow{2}{*}{$\begin{array}{l}\text { Body } \\
\text { weight } \\
\text { (g) }\end{array}$} & \multirow{2}{*}{$\begin{array}{l}\text { Epididymal } \\
\text { adipose tissue } \\
\text { weight } \\
\text { (mg) }\end{array}$} & \multicolumn{3}{|c|}{ Epididymal adipose tissue } \\
\hline & & & & & $\begin{array}{l}\text { cell diam } \\
\text { eter }(\mu \mathrm{m})\end{array}$ & $\begin{array}{l}\text { cell vol- } \\
\text { ume (pl) }\end{array}$ & $\begin{array}{l}\text { cell num- } \\
\text { ber }\left(\times 10^{6}\right)\end{array}$ \\
\hline \multirow{4}{*}{ Normal } & S H & 6 & $28.03^{1)}$ & $474.57 * * * 21$ & $72.96^{* * * *}$ & $229.05 * * *$ & 1.99 \\
\hline & & & 0.79 & 50.08 & 1.57 & 14.24 & 0.27 \\
\hline & SL & 6 & 27.44 & 257.70 & 56.77 & 108.83 & 2. 12 \\
\hline & & & 0.68 & 45.50 & 2. 55 & 15.87 & 0.16 \\
\hline \multirow{4}{*}{ Starvation } & S H & 6 & 22.29 & $377.67 * *$ & $65.11^{* * *}$ & $169.40^{* * *}$ & 2.11 \\
\hline & & & 0.71 & 66.66 & 4.46 & 34.77 & 0.12 \\
\hline & S L & 6 & 22.25 & 191.80 & 48.42 & 76.49 & 2.00 \\
\hline & & & 1.16 & 76.62 & 6.02 & 27.94 & 0.21 \\
\hline
\end{tabular}

1): Mean \pm S.D. 2): Significant difference between SH and SL lines. $* * P<0.01 . * * * P<0.001$. 3): The mice of normal control group were killed at 45 days of age and of starvation group were after 48 hours starvation from 45 days of age.

Table 3. Phenotypic correlations among body weight, epididymal adipose tissue weight, cell diameter, cell volume and cell number pooled within treatment-line subclasses.

\begin{tabular}{lcccc}
\hline & $\begin{array}{c}\text { Epididymal fat } \\
\text { pat weight }\end{array}$ & $\begin{array}{c}\text { Cell } \\
\text { diameter }\end{array}$ & $\begin{array}{c}\text { Cell } \\
\text { volume }\end{array}$ & $\begin{array}{c}\text { Cell } \\
\text { number }\end{array}$ \\
\hline $\begin{array}{c}\text { Body weight } \\
\text { Epididymal fat } \\
\text { pad weight }\end{array}$ & $0.410^{*}$ & $0.457^{*}$ & $0.416^{*}$ & 0.082 \\
$\begin{array}{c}\text { Cell diameter } \\
\text { Cell volume }\end{array}$ & $0.961^{* *}$ & $0.957^{* *}$ & 0.152 \\
\hline
\end{tabular}

Degrees of freedom $=22 . * \mathrm{P}<0.05 . \quad * * \mathrm{P}<0.01$.

are given in Table 3. Body weight was positively correlated $(P<0.05)$ with fat pad weight and fat cell size. Fat pad weight was highly and positively correlated $(\mathrm{P}<$ 0.01 ) with fat cell diameter and cell volume. But there were no significant correlations between fat cell number and other characters. The total fat weight in the epididymal fat pad could be approximated by the product of fat cell number $\times$ fat cell volume $\times$ lipid density. Therefore, the difference in fat accumulation between SH and SL lines was accounted for by the fat cell volume.

Table 4 shows the epididymal adipose lipase activities of SH and SL lines of mice. Although there was no significant line difference in lipase activity expressed per $\mathrm{g}$ wet weight, its activity expressed in the whole tissue basis was significantly higher in $\mathrm{SH}$ than in SL. The lipase activities of both lines were significantly decreased under starvation.

The liver weight and composition, and the incorporation of ${ }^{14} \mathrm{C}$ into liver lipid are given in Table 5 . There were no significant line differences in the weight, moisture, 
Adipose Tissue Cellularity and Lipid Metabolism

Table 4. Epididymal adipose tissue lipase activity of SH and SL lines.

\begin{tabular}{|c|c|c|c|c|c|c|}
\hline \multirow{2}{*}{ Treatment } & \multirow{2}{*}{ Line } & \multirow{2}{*}{$\begin{array}{c}\text { Number } \\
\text { of } \\
\text { mice }\end{array}$} & \multirow{2}{*}{$\begin{array}{l}\text { Body } \\
\text { weight } \\
\text { (g) }\end{array}$} & \multirow{2}{*}{$\begin{array}{c}\text { Epdidymal } \\
\text { fat pad } \\
\text { weight } \\
\text { (g) }\end{array}$} & \multicolumn{2}{|c|}{ Lipase activity } \\
\hline & & & & & $\begin{array}{c}\mu \mathrm{Eq} / \mathrm{g} \text { wet } \\
\text { tissue }\end{array}$ & $\begin{array}{c}\mu \mathrm{Eq} / \text { whole } \\
\text { tissue }\end{array}$ \\
\hline \multirow{4}{*}{ Normal } & $\mathrm{S} \mathrm{H}$ & 6 & $26.42^{11}$ & $0.493 * * 21$ & 12.44 & $6.03^{* * *}$ \\
\hline & & & 1.03 & 0.080 & 2. 39 & 0.88 \\
\hline & S L & 6 & 27.38 & 0.322 & 11.03 & 3.47 \\
\hline & & & 1.05 & 0.076 & 2. 10 & 0.73 \\
\hline \multirow{4}{*}{ Starvation } & $\mathrm{SH}$ & 6 & 21.18 & 0.377 & 6.63 & 2.16 \\
\hline & & & 0.44 & 0.112 & 0.88 & 0.49 \\
\hline & $\mathrm{SL}_{\mathrm{L}}$ & 5 & 22.30 & 0.288 & 6.12 & 1.65 \\
\hline & & & 0.79 & 0.087 & 1.56 & 0.20 \\
\hline
\end{tabular}

1): Mean \pm S.D. 2): Significant difference between $\mathrm{SH}$ and SL lines. $* * \mathrm{P}<0.01$. ***P $<0.001$. 3): The mice of normal control group were killed at 45 days of age and of starvation group were after 48 hours starvation from 45 days of age.

Table 5. The weight, moisture, lipid and FFDM of the liver and the incorporation of 1${ }^{14} \mathrm{C}$-acetate into liver lipid of SH and SL lines.

\begin{tabular}{|c|c|c|c|c|c|c|c|c|c|c|}
\hline & \multirow{3}{*}{ Line } & \multirow{3}{*}{$\begin{array}{c}\text { Number } \\
\text { of } \\
\text { mice }\end{array}$} & \multirow{3}{*}{$\begin{array}{l}\text { Liver } \\
\text { weight }\end{array}$} & \multirow{2}{*}{\multicolumn{3}{|c|}{ Liver composition }} & \multirow{3}{*}{$\begin{array}{c}\text { Number } \\
\text { of } \\
\text { mice }\end{array}$} & \multirow{3}{*}{$\begin{array}{l}\text { Liver } \\
\text { weight }\end{array}$} & \multicolumn{2}{|c|}{ Incorporation } \\
\hline & & & & & & & & & $\mathrm{cpm} \times 10^{8}$ & $\mathrm{cpm} \times 10^{9}$ \\
\hline & & & & Moisture & Lipid & FFDM $^{11}$ & & & $\mathrm{~g}$ liver & tissue \\
\hline & & & (g) & (\%) & $(\%)$ & $(\%)$ & & (g) & & \\
\hline \multirow{4}{*}{ Normal } & $\mathrm{SH}$ & 6 & $1.65^{21}$ & 72.25 & 3.58 & 24.18 & 4 & 1.22 & 5.69 & $6.79 * 3)$ \\
\hline & & & 0.15 & 0.92 & 0.19 & 0.89 & & 0.12 & 2.57 & 2.62 \\
\hline & SL & 6 & 1.65 & 73.55 & 3.14 & 23.32 & 4 & 1.07 & 2.60 & 2.80 \\
\hline & & & 0.15 & 0.62 & 0.45 & 0.26 & & 0.05 & 0.68 & 0.84 \\
\hline \multirow{4}{*}{ Starvation } & $\mathrm{S} \mathrm{H}$ & 6 & 0.89 & 67.58 & 7.43 & 24.99 & 6 & 0.81 & $4.61 *$ & $4.04^{*}$ \\
\hline & & & 0.06 & 0.46 & 1.02 & 0.97 & & 0.02 & 0.63 & 0.88 \\
\hline & S L & 6 & 0.88 & 68.47 & 6.40 & 25.14 & 6 & 0.81 & 3.06 & 2.47 \\
\hline & & & 0.10 & 2.08 & 2.59 & 0.82 & & 0.08 & 0.85 & $0.7 \mathrm{I}$ \\
\hline
\end{tabular}

1): FFDM: Fat Free Dry Matter. 2): Mean \pm S.D. 3): Significant difference between SH and SL lines. $* \mathrm{P}<0.05$. 4): The mice of normal control group were killed at 45 days of age and of starvation group were after 48 hours starvation from 45 days of age.

lipid and FFDM of liver of both treatment groups. In the starvation group, liver weight and liver moisture were smaller, but liver lipid was larger than in the normal control group. The incorporation of $1^{1-{ }^{14}} \mathrm{C}$-acetate expressed per $\mathrm{g}$ liver into liver lipid was higher in SH than in SL in both groups. And the incorporation of $1^{14} \mathrm{C}$-acetate into liver lipid expressed in the whole liver basis was significantly higher in SH than in $\mathrm{SL}$ in both treatment groups. In the starvation group, although $1-{ }^{14} \mathrm{C}$-acetate was injected twice as much as the normal control group, the ${ }^{14} \mathrm{C}$ incorporation into liver lipid was reduced in two lines. 


\section{Discussion}

Present results showed that the two way selection for resistance to starvation had brought about correlated response of body fat, fat free dry matter and water content without changing body weight, as reported before ${ }^{2}$.

Recently, many investigations about adipose tissue cellularity of mice and rats were reported. JoHNSON and $\mathrm{HIRSCH}^{9}$ classified the genetic and experimental obesity in mice and rats into either hypertrophic or hypertrophic-hyperplastic form. And EISEN et al. ${ }^{10)}$ reported that the mice selected for rapid growth have larger cell size and more cell numbers than the mice of unselected control. From these reports, it is generally concluded that fat accumulation was attained by the increase of adipose tissue fat cell number and cell size. Therefore, it was necessary to investigate whether the difference in fat accumulation between SH and SL lines was accounted for by the fat cell number or cell size or both of them. Present results showed that the two way selection for resistance to starvation had brought about the correlated increase or decrease of adipose fat cell size without change of fat cell number. It was known that fat cell number of mice was determined before weaning', and that the nutritional factor at the early process of development was more important to determine adipose fat cell number than genetical factor ${ }^{11}$. From the result that there was no difference in litter weight gain during suckling between SH and SL lines (unpublished), it was estimated that the milking ability of SH was similar to SL. Therefore, the difference in fat cell size may be resulted rather from the correlated genetic response in lipid metabolism than from the nutritional condition for pups.

As the adipose tissue weight is very variable with the change of physiological condition, for example, in case of starvation, it is important to select the index to express the lipase activity, such as whole tissue, cell number, DNA etc., so as to reflect the physiological condition ${ }^{12}$. In the present study lipase activity was expressed in the whole tissue basis. The higher total activity in SH than in SL was suggested. Mizunuma et al. ${ }^{13)}$ reported that the adipose tissue lipase activity expressed in the whole tissue basis was significantly higher in aged rats, which had larger cell size than young rats, than in young ones. Furthermore, from the comparision of lipoprotein lipase activity and hormone-sensitive lipase activity both expressed on a cellular basis (DNA) between genetical obese and lean breed pigs, it was suggested that difference in obesity between these breeds was not the result of differences in ability to mobilize fat but the result of an increase rate of lipid deposition in the obese pigs ${ }^{14}$. Judging from these facts, it is suggested that the lipase activity of SH line with larger fat cell size is higher than that of SL with smaller fat cell size. Generally, adipose tissue contains at least two triacylglycerol lipases; one is a lipoprotein lipase and the other is a hormone-sensitive lipase. But recently, the idea was reported that these two lipases might be identical, not different enzymes. That is, these lipases might have immunochemically identical enzyme molecules and the adipose tissue lipase measured by adding serum was named lipoprotein lipase, while one measured without adding 
serum was named hormon-sensitive lipase ${ }^{15)}$. Accordingly, in the present experiment, whole adipose lipase activity was measured regardless of the existence of these two lipases.

There was no difference in liver lipid accumulation between SH and SL lines but the incorporation of $1{ }^{14} \mathrm{C}$-acetate into liver Lipid was higher in SH than in SL line. From these results, it is suggested that the turnover of lipid in the liver of SH line may be higher than that of SL. In a series of investigations related to lipid metabolism in experimental and genetic obese mice, BATES et al. ${ }^{18)}$ showed that the incorporation of ${ }^{14} \mathrm{C}$ into liver and carcass fatty tissues was higher in obese mice than in normal control. Furthermore, these obese mice were classified into "regulatory" obesity, where the impairment was in the central mechanism regulating food intake, and "metabolic" obesity, where the primary lesion was an inborn or acquired error in the metabolism of tissues, per se, as described by MAYER ${ }^{17}$. Although SH line is not "so called" obese mice, body fat content and body fat percentage of SH line were higher than those of SL. And not only in the normal control group but also in the starvation group, the incorporation of $1{ }^{14} \mathrm{C}$-acetate into the liver lipid was higher in $\mathrm{SH}$ than in SL. According to the definition of MAYER et al., it may be said that SH line was similar metabolic mechanism to "metabolic" obesity form as compared with SL.

When animals were starved, in general, they undergo metabolic adaptation in order to derive energy from adipose tissue and to conserve their protein reserves as effciently as possible ${ }^{17}$. From this, it is possible that the selection for resistance to starvation is the indirect selection for body fat accumulation. And present investigation suggested that the difference in body fat content between SH and SL lines selected for resistance to starvation was accounted for by the adipose tissue cell size which was brought about as the correlated genetic response in the lipid metabolism between $\mathrm{SH}$ and SL lines.

\section{References}

1) Yamagishi, T., Jpn. J. Zootech. Sci., 46: 219-225. 1975.

2) Suzuki, K., T. Yamagishi and Y. Mizuma, Jpn. J. Zootech. Sci., 49: 243-249. 1978.

3) Suzuki, K., T. Yamagishi and Y. Mizuma, Tohoku J. Agr. Res., 29: 79-87. 1978.

4) Frings, C.S. and R. T. Dunn, Am. J. Clin. Path., 53: 89-91. 1970.

5) ZuRkowskr, P., Clin. Chem., 101: 451-453. 1964.

6) Bligh, E.G. and W. J. Dyer., Can. J. Biochem. Physiol., 37: 911-917. 1959.

7) Rodbell, M., J. Biol. Chem., 239: 375-380. 1964.

8) Van Bruggen, J. T., T. T. Hutchens, C.K. Claycomb, W. J. Cathey and E. S. West, J. Biol. Chem., 196: 389-394. 1952.

9) Johnson, P. R. and J. Hirsch, J. Lip. Res., 13: 2-11. 1972.

10) Eisen, E. J., J. F. Hayes, C. E. Allen, H. Bakker and J. Nagai, Growth, 42: 7-25. 1978.

11) Muto, Y, and N. Shinohara, Metabolism., 9: 935-948. 1972.

12) ОкUdA, H. and S. Fujı, Yukagaku. 23: 281-289. 1974.

13) Mrzunuma, T., F. Sato, Y. Kishino and H. Okuda, Food and Nutrition, 30: 7-13. 1977.

14) Weisenburg, C. L. and C. E. Allen, J.Anim. Sci. (Abs), 37: 293. 1973.

15) ОкudA, Н. and S. FuJ1I, J, Biochem., 73: 1195-1203. 1973.

16) Bates, M.W., C. Zomzely and J. Mayer, Am. J. Physiol,, 181: 187-190. 1955.

17) Mayer, J., in the Handbook of Physiology, Section 5 Adipose tissue: 645-651. American Physiological Society, Washington, D.C. 1965. 
18) Cah1Ll, G. F. Jr., New Engl. J. Med.,, 282: 668-675. 1970.

\title{
飢餓抵抗性選抜系マウスの脂肪組繊の細胞 特性之脂質代謝に関する研究
}

\author{
鈴大啓一・山岸敏宏・水間 豊 \\ 東北大学農学部，仙台市 980
}

\begin{abstract}
㖣餓抵抗性高，低選抜采マウス（SH，SL）の脂留代謝 の違いを明らかにするため，画系統の、ウスについて

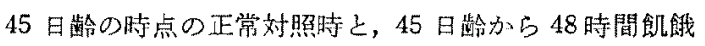
条件下儿置加れた時の体の化学的槥成，血し上う中総脂 質，総コレステロールおよびダルコース，副等丸脂肪組 織の脂肪細胞の数と大きさ，副䔂丸脂肪組織のリパーゼ

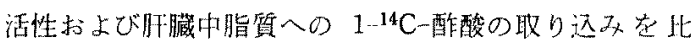

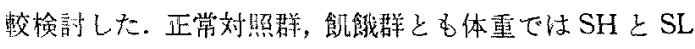
の閒に差は認如しないが，SH は SLより脂肪含量が 多く，水分已脱脂乾物含量は少なかった，正常群では，

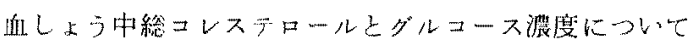
SH がSL より高かった。副芧丸脂肪組織の細胞の数と 大きさの比較加ら，慨餓抵抗性に関方巽抜は，相関反
\end{abstract}

心として脂肪細胞の数は变えず，細胞の大きさを变员る ことが明らかとなった。副等丸脂肪組織全体あたりで表 示した脂肪組織りパーゼ结性は，正常群では SH が SL より有意に高く，即餓群でも有意ではないが $\mathrm{SH}$ が SL より高かった．肝臓中脂質含量では両系統間に差は認め られなかったが，肺蔵中脂質への $1{ }^{14} \mathrm{C}$-酷酸の取り达み は SH が SL より有意に高加た。以上から， SH SL 系のマウスは脂質代謝において遗伝的に明らか江異 なっており，この差が画系統のマウスの脂肪緼織の細胞 の大きさの差を引き起こし，さらに体脂肪蓄積の違いを むたらしたものし将えられる。

日畜会㪕，51(4)：293-300，1980 